\title{
Consumption in the Dark: Estimating Unrecorded Expenditures of Households in Croatia
}

\section{Bruno Škrinjarić}

The Institute of Economics, Zagreb, Croatia

bskrinjaric@eizg.hr

\section{Vedran Recher}

The Institute of Economics, Zagreb, Croatia

vrecher@eizg.hr

\section{Jelena Budak}

The Institute of Economics, Zagreb, Croatia

jbudak@eizg.hr

\author{
CroEconSur \\ Vol. 19 \\ No. 2 \\ December 2017 \\ pp. 135-167
}

Received: July 25, 2017

Accepted: November 17, 2017

Review Article

doi:10.15179/ces.19.2.5

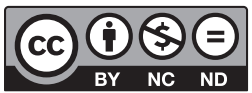

\section{Abstract}

The unofficial sector is generally regarded as an important liability for the development of a post-transitional society. In this paper we adopt a new approach to estimate the unofficial economy by estimating the unrecorded consumption of households in Croatia. This is done by means of conducting a nationally representative survey on payment habits of the Croatian consumers and by pairing these data with the household consumption survey. Our main focus concerns cash payments without an issued receipt, which is assumed to represent the unofficial part of transactions. In this way we circumvent some notable deficiencies of direct surveys on income reporting and selective reviews. 
We find that the part of unofficial economy arising from household consumption was around 0.69 percent of GDP in 2014.

Keywords: unofficial economy, household consumption survey, Croatia, post-transition

JEL classification: E21, E26, P39

\section{Introduction}

There is a widespread attempt by the governments around the world to channel all economic activities into official economy. In spite of these efforts, a part of economic transactions inevitably remains unrecorded. The post-transitional countries are generally more prone to all kinds of hidden activities, such as tax evasion, black labor market, illegal economic activities, corruption, money laundering etc. (see for example, Johnson et al., 2000) and Croatia is not an exception. When examining the issue of unofficial economy, one has an uneasy task of defining this phenomenon (Schneider, 2011). Schneider and Enste (2013) note that the difficulty in defining the informal economy ${ }^{1}$ stems from the fact that it encompasses numerous economic activities, such as goods and services produced and consumed within the households, forms of illicit work, illegal employment and social fraud, and criminal economic activities. Although the body of knowledge on the unofficial economy is extensive, Schneider and Buehn (2016: 30) note that "much more research is needed with respect to estimation methodology and empirical results for different countries and periods". Our paper contributes to the literature by estimating the size of unofficial economy in a post-transitional country, i.e. Croatia, using a different and thus far a unique approach by focusing on goods and services consumed by the households. In this context, the operative definition of unofficial economy will arise from the household consumption survey.

1 Terms underground economy, unofficial economy, grey economy, hidden economy, shadow economy, unreported economy, and unofficial activity, are often used in the literature denoting the same phenomenon. 
We define unofficial economy as a trade of goods and services for which no invoice was issued. This operative definition is very similar to the one used in Madžarević-Šujster (2002: 119), who defines informal economy as "legal activity which is not reported in order to elude paying taxes".

Keeping in mind different estimation methods on the one hand, and the persistent unofficial economy problem in Croatia on the other, it is argued that there is a need for empirical evidence of patterns and size of the unofficial economy in Croatia. The main motivation behind this paper is that it offers new insights into patterns of household consumption and provides estimates on that part of the shadow economy hidden in the consumption of households. This is done by using a new approach, which is somewhat similar to the one used in the Ernst and Young (2016) report. Using the survey data on issued receipts for cash payments based on real experience of the Croatian citizens, we deduce the informal sector from the proportion of these transactions.

The paper is structured as follows. The literature review on unofficial economy research studies, particularly in Croatia, is provided in the next section. It is followed by survey methodology and data description used for the analysis of survey results and estimates of the size of unofficial economy in Croatia, which are presented in the central part of the paper. The last section provides a conclusion.

\section{Literature Review}

Broadly, the estimation methodology concerning informal economy can be divided into direct and indirect approach (Schneider, 2003). These approaches are summarized in Table 1 .

The issue of informal economy has received a fair amount of scholarly attention in Croatia. The pioneering works of estimating the unofficial economy for Croatia using different methods date from $1997^{2}$. These estimations concerning

2 Papers were published in the special issue of the journal Financijska teorija i praksa, 21(1997), http://www.ijf.hr/ hr/publikacije/casopisi/12/financijska-teorija-i-praksa/104/vol-21-1997/226/. 
the shadow economy, using the discrepancy method, were around 28 percent of the GDP in the mid-1990s. Estimations by Madžarević and Mikulić (1997) were included as a benchmark for Croatia in a comparative study of shadow economy conducted worldwide by Schneider and Enste (1998).

Table 1: Methodology for the Estimation of the Share of the Informal Sector in the Economy

\begin{tabular}{|c|c|c|c|}
\hline Approach & Method & Short description & Deficiency \\
\hline \multirow{2}{*}{ Direct (micro) } & Surveys & $\begin{array}{l}\text { Surveys on population samples } \\
\text { based on voluntary responses }\end{array}$ & $\begin{array}{l}\text { Accuracy of survey data and } \\
\text { underreporting (e.g. would } \\
\text { people want to admit tax } \\
\text { evasion?) }\end{array}$ \\
\hline & $\begin{array}{l}\text { Selective } \\
\text { reviews }\end{array}$ & $\begin{array}{l}\text { Difference between reported } \\
\text { income and income estimated } \\
\text { in a review }\end{array}$ & $\begin{array}{l}\text { Non-random sample, based } \\
\text { only on evidence found by tax } \\
\text { authorities }\end{array}$ \\
\hline \multirow{5}{*}{ Indirect (macro) } & $\begin{array}{l}\text { Money } \\
\text { demand* }\end{array}$ & $\begin{array}{l}\text { Relationship between a } \\
\text { demand for money and tax } \\
\text { burden as a cause of escape into } \\
\text { informal economy }\end{array}$ & $\begin{array}{l}\text { Based only on cash flows, not } \\
\text { considering other important } \\
\text { factors besides tax burden }\end{array}$ \\
\hline & $\begin{array}{l}\text { Physical } \\
\text { input* }\end{array}$ & $\begin{array}{l}\text { Approximation by electricity } \\
\text { consumption }\end{array}$ & $\begin{array}{l}\text { Not all informal activities need } \\
\text { electricity; difficult to take into } \\
\text { account the technical advances } \\
\text { in electricity consumption }\end{array}$ \\
\hline & $\begin{array}{l}\text { National } \\
\text { accounting }\end{array}$ & $\begin{array}{l}\text { Discrepancy between income } \\
\text { and expenditure }\end{array}$ & $\begin{array}{l}\text { Omissions and errors inside the } \\
\text { national accounting data }\end{array}$ \\
\hline & Labor force & $\begin{array}{l}\text { Discrepancy between the } \\
\text { official and actual labor force }\end{array}$ & $\begin{array}{l}\text { 'Moonlighting' - working } \\
\text { in both official and unofficial } \\
\text { sectors at the same time }\end{array}$ \\
\hline & $\begin{array}{l}\text { The Lackó } \\
\text { method }\end{array}$ & $\begin{array}{l}\text { Electricity consumption in } \\
\text { households }\end{array}$ & $\begin{array}{l}\text { Not all informal activities need } \\
\text { electricity; informal activities } \\
\text { take place out of households }\end{array}$ \\
\hline Modeling & SEM & $\begin{array}{l}\text { Informal sector as a latent } \\
\text { variable in structural equation } \\
\text { modeling }\end{array}$ & Data availability \\
\hline
\end{tabular}

Note: ${ }^{*}$ Hanousek and Palda (2006) argued that the parameters of money demand and electricity demand are too varying in transition economies for the above estimation methods concerning the size of the underground economy to be used.

Source: Authors' adaptation from Schneider (2003) and Schneider and Enste (2013). For a detailed discussion of strengths and weaknesses of methods, see Schneider and Buehn (2016).

The research of unofficial economy in Croatia made tracks at the turn of the century (Ott, 2002; Šošić and Faulend, 2002; Karajić, 2002; Galinec, 2002; Stučka, 2002; Madžarević-Šujster, 2002; Madžarević-Šujster and Mikulić, 2002; Schneider, 2003). However, due to the lack of data, robust empirical research of 
the topic is scarce and results differ as expected due to the different estimation methods used (for a review, see Bejaković, 2015). The size of unofficial economy varies largely among countries, with comparative studies showing higher levels of unofficial economy in transition compared to developed countries (Schneider, 2015). One of the rare studies comparing Croatia with similar countries in the region, namely Slovenia and Bosnia and Herzegovina $(\mathrm{B} \& \mathrm{H})$, is that of Nastav and Bojnec (2007), where the authors concluded that the unofficial economymeasured by the labor force method as a share in GDP-is decreasing in observed countries since 1994. However, B\&H keeps performing the worst. The trend of the unofficial economy decrease in Croatia for the period 2001-2007 (measured also by labor method), was confirmed by Švec (2009). She noted that Croatia still fares poorly when compared to other EU countries.

Karajić (2002) takes a step back from the empirical estimations and uses a qualitative approach to illustrate the interconnection of informal economy and poverty. Author claims that both issues are the symptoms of a transition crisis and consequential attrition of social, moral and just values. Furthermore, he argues that informal economy deepens the gap between the poor and the rest of the society.

Šošić and Faulend (2002) estimate the informal economy based on the amount of foreign currency in circulation. They compare their approach with the results from the Gutmann method and the electricity consumption method and show that: a) informal economy estimated with Gutmann's method shows largest variability; b) informal economy estimated with a method based on foreign currency is similar to the estimation based on electricity consumption. Their results for 1995-2000 show that the average share of informal economy in the Croatian GDP was around 25 and 30 percent.

Schneider (2003) largely supports these findings. He also finds that the average share of informal economy in Croatia for 2000-2001 was at 32.4 percent of GDP based on the DYMIMIC method, which is in fact larger when compared 
to the previous period. He also finds that the percentage of labor force active in the informal sector was around 27 percent of the total population for the year 1999. At that time, other studies indicated that the prevalent form of unofficial economy is the income deriving from unreported labor (Lovrinčević, Mikulić and Nikšić-Paulić, 2002).

Madžarević-Šujster (2002) estimates the size of tax evasion in Croatia for the period 1994-2000. The estimations show that the tax evasion amounted up to around 10 percent of GDP in the observed period with the exception of 2000 when it fell to around 7 percent of GDP.

Madžarević-Šujster and Mikulić (2002) estimate the informal economy based on discrepancies in national accounts. They define informal economy simply as unrecorded economy. They establish that for the period 1990-1995, the average size of informal economy was around 25 percent of GDP, and for the period 1996-2000, around 10 percent of GDP. Their results are largely in line with the estimations concerning tax evasion in Madžarević-Šujster (2002), but are significantly lower for the second period in comparison to Šošić and Faulend (2002).

Stučka (2002) evaluates the value and volume of informal economy based on the difference between tourist flows in Croatia and tourist flows registered in Croatia. Author estimates that the informal part of the tourist sector amounts up to around 0.6 percent of GDP in the period 1998-2000, with a slight tendency of growth in the observed period. Considering the general growth in the tourism headline figures in the following years, one would expect that this share only increased since then.

In a more recent paper, Švec (2009) assesses the share of informal economy in the period 2001-2007 based on labor force approach, using the administrative as well as Labor Force Survey data. The author shows that the informal employment averaged around 3.6 percent in the stated period. 
The size of the unofficial economy in Croatia has been evaluated for national statistics purposes within the process of Croatia's accession to the European Union (EU)³. Lovrinčević, Mikulić, and Galić Nagyszombaty (2005) estimated the size of the informal economy in Croatia based on Eurostat methodology. Their results are closer to those obtained by Madžarević-Šujster and Mikulić (2002) and Madžarević-Šujster (2002), which means that the size of the unofficial economy in Croatia could be substantially lower when compared to some other estimations presented above. They find that in the period 1998-2002 the share of the informal sector in GDP was around 15 percent, which should be ascribed to the conservative method applied.

Eurostat's tabular approach produces more conservative estimates of underground economy when compared to other methods such as the econometric modeling based on the MIMIC approach (multiple indicators - multiple causes). MIMIC methodology, which is developed and updated by Schneider and coauthors (Schneider and Enste, 2000; Schneider, Buehn and Montenegro, 2010; Manes, Schneider and Tchetchik, 2016), indicates an extremely high share of unofficial economy in the Western Balkan countries in the range between 30 to 40 percent of GDP. Manes, Schneider and Tchetchik (2016) find that the size of the shadow economy decreases in Croatia, form 34 percent of GDP in 1999 to 28 percent of GDP in 2015.

Although the research interest in the size of unofficial economy in Croatia has slowly evaporated in the last decade, some recent studies deal with this issue from a specific point of view (e.g. Maršić and Oreški, 2016; Franić and Williams, 2014; Williams, 2014), suggesting that the unofficial economy continues to be an issue of substance for the Croatian economy. The problems stemming from, or being closely related to the unofficial economy, are corruption (Lovrinčević, Mikulić and Budak, 2006), tax evasion (Ott, 2004) and black labor markets (Barić and Williams, 2013). Payment without an issued receipt, in particular, in services 
and retail sector and in transactions with physical consumers, is considered to be a pertinent problem in Croatia. Law on fiscalization by cash payment enacted from January 2013 aimed to overcome the grey economy sector, to ensure transparent transactions, better tax services, and the stabilization of budget imbalances (Croatian Parliament Decision 2822, 2012). Fiscalization enforced the receipts issue and the register of transactions in the 'grey zones'. Marković and Pavić (2013) showed that upon the introduction of fiscalization, the reported turnover in the catering industry in Croatia increased.

Obviously, the size of the underground economy estimated by different methods is not comparable and there is no consensus on the one appropriate method to be applied. By adopting a new approach to the issue of the unofficial sector, we do not estimate its total share in the economy, but we do estimate the total size of the unofficial sector hidden in the consumption of households. Expenditures of households are the most important part of the final demand, but unrecorded transactions might appear in other categories of the final demand. For example, the consumption of foreign tourists is not captured in national accounts as personal consumption. Furthermore, unrecorded transactions we measure here are 'committed' because the buyer was aware that the receipt was not issued. There are as well situations known in the European tax regulations as tax evasion without complicity (Commission Decision 98/5277EC, 1998) where the buyer is not aware of the manipulations leading to underreporting revenues. Such underreported transactions not captured in the survey are cases of a false or a double issued invoice, or a posteriori cancelation of transactions by the seller. Some proportion of unrecorded revenues might occur even in the case of electronic or card payment ${ }^{4}$. This classifies our estimation method as the conservative one.

One obvious and substantial advantage of this approach is the elimination of one specific type of underreporting bias in the survey. Namely, by surveying the participants on their consumption patterns and the type of payments they use, it has been established that they lack a clear incentive to provide false information.

4 We acknowledge the comment of the reviewer bringing up this issue. 
More precisely, by not mentioning that the research is in any way connected to the shadow economy, we do not alert them to be cautios when answering questions about their everyday habits. However, underreporting bias using the survey data might not be totally eliminated because the Household Budget Survey data were taken as the base of estimation of personal consumption and some items in the Survey data might be underestimated.

\section{Methodology and Data Description}

Dataset used in this research consists of primary data collected through a questionnaire, amended with secondary data from the Household Budget Survey for 2014 (CBS, 2016) obtained via the Croatian Bureau of Statistics (CBS). The questionnaire was developed by the authors and enclosed in the Appendix ${ }^{6}$.

In the development of the questionnaire we needed to take into account some peculiarities of the research question. For example, in Croatia, consumers are able to buy the same product (for example, vegetables) in supermarkets, in e-commerce or at open markets. Obviously, the type of payment used will not only depend on consumer preferences, but also on the availability of different types of payment methods. Therefore, we needed to phrase the survey items adequately to capture all the possibilities available to the consumers. In survey design we implicitly assumed the following: (i) electronic payments (including card payments in payments via Internet) are always part of the formal economy; (ii) cash payments can be part of the formal or the informal economy, conditional on whether the invoice was issued or not. The first assumption is in line with Schneider (2013: 7) who writes that "the shadow economy is clearly a cash-based economy, and cash is the fuel in its engine". The second assumption is also highly

5 It is recognized in the literature that respondents underreport the consumption of tobacco or alcoholic beverages and overestimate the desirable expenses (e.g. for books or cultural events). See Stockwell et al. (2004) on underreporting of alcohol consumption in household surveys, Luepker et al. (1989) on under-reporting smoking in telephone interviews, or Szolnoki and Hoffmann (2013) on survey bias in the recording of wine consumption.

6 We appreciate the advice and the assistance of colleagues in testing the questionnaire. Questions unrelated to this research have been omitted. 
realistic since the introduction of fiscal cash registers guarantees a report for every issued invoice. Therefore, if the seller of goods and services does not issue an invoice it is reasonable to assume he did so on purpose to hide the transaction.

The survey was conducted on a nationally representative sample of 500 Croatian citizens aged 18-65, in a period from November 2016 to January 2017. The sample is representative of the Croatian population by three categories: gender, age, and spatial distribution (by counties) as presented in Table A.1 of the Appendix. Initial distribution of population by categories is taken from the population census available from the CBS. The sampling frame was publicly available via the Croatian Telecom phonebook. Although the decreasing landline telephone ownership $^{7}$ could lead to potentially biased results, representative geographical coverage and a lower cost compared to face-to-face surveys contribute to the advantages of telephone surveys. After the initial selection of a desired county, a random selection of the first two letters of a surname was the first phase of the search. After that, a random page was selected and a random participant was selected from the same page. To complete 500 surveys, 4,923 phone calls were made, which indicates a response rate of 10.16 percent. However, a low response rate was not an issue because the target of the net sample size of 500 respondents was reached. For the categories that have been used for sample stratification (gender, age, region), the share in the sample closely matches the share in population (\% in parentheses) indicating the representativeness of the sample, so no post-stratification was needed. Sample characteristics are presented in Table 2.

The distribution of respondents is fairly equally represented by both sexes with a slight advantage of men ( 51.4 percent vs. 48.6 percent). Based on the age distribution of the respondents, the leading age group is between 45-54 years with a share of 24 percent, while the least represented are the young adults between 18-24 years, with 13 percent share.

7 The total number of landlines in Croatia decreased slightly in 2016 compared to the previous year (Božić, 2017), yet the $1,295,134$ thousand landline telephones in a country with 4.5 million inhabitants indicates a satisfactory coverage. 
Table 2: Sample Characteristics, $N=500$

\begin{tabular}{|c|c|c|c|}
\hline $\begin{array}{c}\text { Category (share in the } \\
\left.\text { population }{ }^{*}\right)\end{array}$ & $\begin{array}{c}\text { Participants } \\
\text { (share in the } \\
\text { sample) }\end{array}$ & Category & $\begin{array}{c}\text { Participants } \\
\text { (share in the } \\
\text { sample) }\end{array}$ \\
\hline \multicolumn{2}{|l|}{ Gender } & \multicolumn{2}{|l|}{ Education } \\
\hline Female $(51.8 \%)$ & $243(48.6 \%)$ & Primary or less & $23(4.6 \%)$ \\
\hline Male $(49.8 \%)$ & $257(51.4 \%)$ & Secondary & $279(55.8 \%)$ \\
\hline \multirow{2}{*}{\multicolumn{2}{|c|}{ Age }} & Tertiary & $174(34.8 \%)$ \\
\hline & & Postgraduate/PhD & $24(4.8 \%)$ \\
\hline $18-24(12.3 \%)$ & $65(13.0 \%)$ & \multirow{2}{*}{\multicolumn{2}{|c|}{ Profession/vocation }} \\
\hline $25-34(21.6 \%)$ & $109(21.8 \%)$ & & \\
\hline $35-44(21.1 \%)$ & $105(21.0 \%)$ & Entrepreneur & $22(4.4 \%)$ \\
\hline $45-54(23.2 \%)$ & $120(24.0 \%)$ & Manager & $13(2.6 \%)$ \\
\hline $55-64(21.7 \%)$ & $101(20.2 \%)$ & Expert (tertiary education or more) & $106(21.2 \%)$ \\
\hline \multirow{2}{*}{\multicolumn{2}{|c|}{ Region** $^{* *}$}} & Clerk (in the office) & $66(13.2 \%)$ \\
\hline & & Worker & $140(28.0 \%)$ \\
\hline Central Croatia $(34.9 \%)$ & $188(37.6 \%)$ & Retiree & $58(11.6 \%)$ \\
\hline Northwest Croatia $(12.9 \%)$ & $62(12.4 \%)$ & Student/pupil & $48(9.6 \%)$ \\
\hline East Croatia $(20.1 \%)$ & $93(18.6 \%)$ & Unemployed & $47(9.4 \%)$ \\
\hline North Adriatic and Lika $(12.7 \%)$ & $67(13.4 \%)$ & \multirow{2}{*}{\multicolumn{2}{|c|}{ Total household earnings (HRK) }} \\
\hline $\begin{array}{l}\text { Middle and South Adriatic } \\
(19.4 \%)\end{array}$ & $90(18 \%)$ & & \\
\hline \multirow{2}{*}{\multicolumn{2}{|c|}{ Size of the settlement (no. of inhabitants) }} & 2,500 or less & $31(6.2 \%)$ \\
\hline & & $2,501-5,000$ & $85(17.0 \%)$ \\
\hline 10,000 or less & $176(35.2 \%)$ & $5,001-7,500$ & $94(18.8 \%)$ \\
\hline $10,001-50,000$ & $137(27.4 \%)$ & $7,501-10,000$ & $108(21.6 \%)$ \\
\hline $50,001-100,000$ & $35(7.0 \%)$ & $10,001-12,500$ & $68(13.6 \%)$ \\
\hline \multirow[t]{2}{*}{ More than 100,000} & $152(30.4 \%)$ & $12,501-15,000$ & $55(11.0 \%)$ \\
\hline & & More than 15,000 & $59(11.8 \%)$ \\
\hline
\end{tabular}

Notes: * CBS, 2013. ${ }^{* *}$ Regions are based on Table A. 2 of the Appendix.

Source: Authors' calculation.

Other age groups are roughly equally represented with a share of around 20 percent. Most respondents came from Central Croatia (37.6 percent) and the smallest percentage comes from the Northwest Croatia (12.4 percent). Looking at the size of the settlement, rural areas with less than 10,000 inhabitants and large cities with a population over 100,000 inhabitants are mostly represented (35.2 percent and 20.4 percent, respectively). Educational background of 
respondents is skewed toward those with high-school education (55.8 percent), followed by respondents with university or higher education (34.8 percent). Proportion of respondents with primary education and with a Master's or a $\mathrm{PhD}$ degree is virtually identical ( 4.7 percent vs. 4.8 percent, respectively). In terms of occupation, most of respondents are employed as workers ( 28 percent), followed by experts (21.2 percent) and clerks who mostly work in offices (13.2 percent). Finally, 63.6 percent of respondents came from households with a total income of up to HRK 10,000 per month, while other households included in the survey climb above that figure. The most represented, accounting for about one-fifth (21.6 percent) of the entire sample are respondents with a monthly household income between HRK 7,051 to 10,000.

The second source of our data is the Household Budget Survey (HBS) for 2014. The Survey was carried out by the CBS on a random sample of 2,029 private households throughout 2014. It is important to mention that we are not in possession of full survey data, i.e. individual answers, but rather the average personal consumption expenditures figures by household in 2014, which is publicly available. These data were first released in December 2015, but the version we are using is the updated version dating from April 2016. Expenditure categories were presented in Croatian kuna (HRK) but were calculated in euro (EUR) for the purpose of this study using the average HRK/EUR exchange rate for $2014^{8}$.

The methodology used in this research is as follows. Since the expenditure groups in $\mathrm{HBS}^{9}$ are somewhat different to those used in our survey, the first step was to match those two groups. The matching process is done as presented in Table A.3 of the Appendix. The matching was not one-to-one which meant that some expenditure groups from both the HBS and our survey were exempt from analysis. Originally, according to HBS, total consumption expenditures amounted up to EUR 10,657.25 per household on average, while after the

$8 \quad$ EUR 1 = HRK 7.63001.

9 Grouped by Classification of Individual Consumption by Purpose - COICOP, 2013. 
exemption of those groups not covered in our survey, this figure dropped down to EUR 10,024.10, which is a loss of 5.94 percent of the original expenditure.

The next step is solely based on our survey data. We start by calculating the shares of each possible method of payment (cards, electronic payment or cash) for each of the expenditure groups defined in the first step. As stated before, our initial assumption states that every payment made by either a credit (or debitno distinction was made between those two) card, or electronically, ends up with an invoice. This is backed up by the fact that every transaction via any of those media leaves a transaction record on several different places (the firm where those goods/services are purchased, the buyers' and sellers' banks, and possibly others). This is certainly not the case when paying with cash, as these transactions can be easily manipulated. This is why in our survey we asked an additional question to every respondent who chose cash as their method of payment for certain goods/ services-whether or not he/she received an invoice for that transaction. This information enabled us to calculate the share of transactions that were paid by cash for which no invoice was issued. So, in total, we ended up with four shares for each expenditure group: share of payment by cards, share of electronic payment, share of payment by cash with an issued receipt and share of payment by cash without an issued receipt. The latter share is used as our proxy for the shadow economy in Croatia. The final step involved multiplying these calculated shares with the expenditure for different expenditure groups calculated in step two.

\section{Data Analysis and Discussion}

Figure 1 presents a distribution of payment methods for different expenditure groups, sorted in a declining order by the share of cash payments. The figure shows that accommodation services (like hotels), and equipment and appliances for the house and garden are paid by cash in only about a quarter of cases. These two expenditure groups, together with package holidays; clothing and footwear; 
games, toys and hobbies; fuel; and sports and recreation are in most cases paid by a credit or debit card. Electronic payment is mostly used to pay for health insurance, telephone and telefax services, utilities, and property insurance.

At the other end of the spectrum there are domestic and household services like gardeners and nannies; and maintenance and repair of dwellings, which are exclusively paid by cash. Expenditure groups, where over 90 percent of all payments are paid in cash also include: personal grooming establishments (hairdressers, beauty salons etc.); local transport (busses, trams etc.); postal services and catering services (restaurants, bars etc.). Intuitively, this is what we expected to find-most of these goods and services are offered by either small or micro companies or crafts who do not offer any form of cashless payment or it may well be that these services are not registered at all and can only accept cash 'under the table' as a compensation. This is also confirmed in Figure 2, which shows the distribution of giving out receipts/invoices according to different expenditure categories when dealing with cash only.

Figure 1: Methods of Payment for Different Expenditure Groups

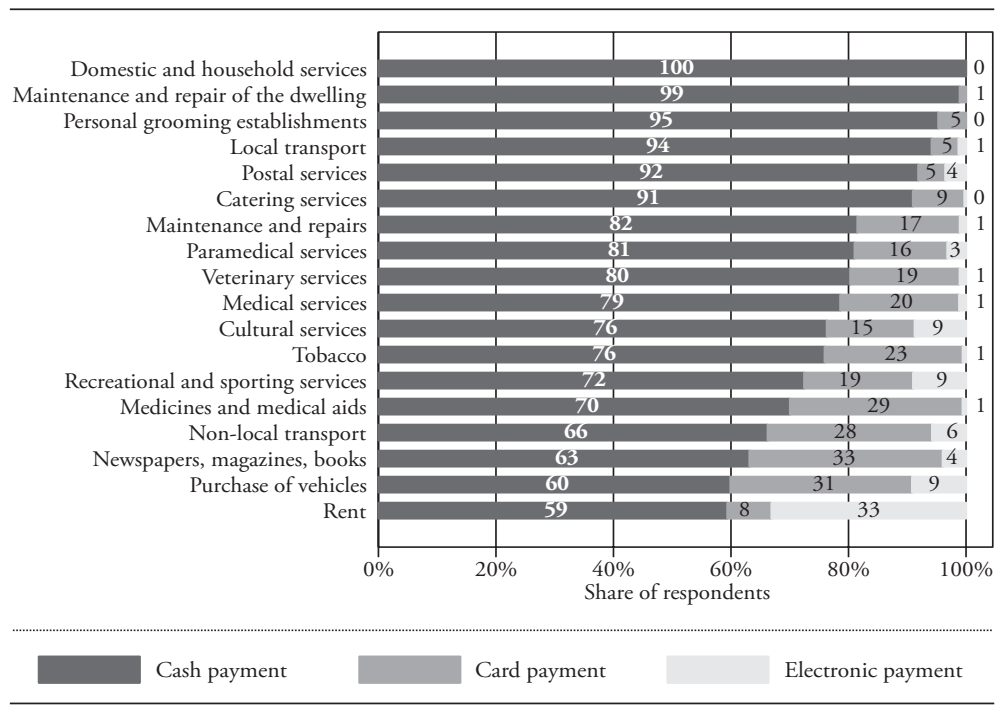


Figure 1: Methods of Payment for Different Expenditure Groups (Continued)

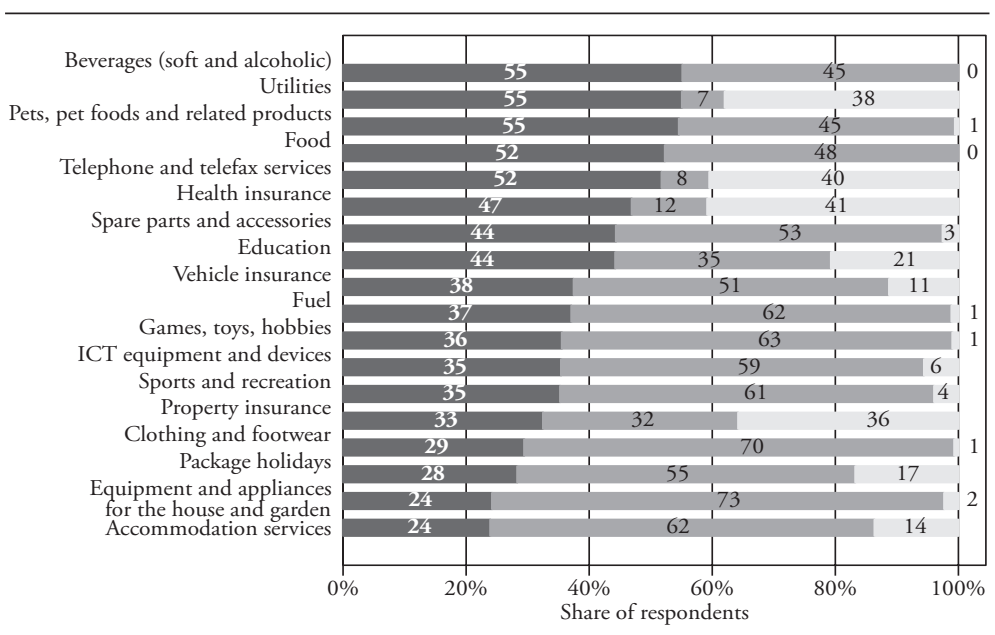

Source: Authors' calculation.

Figure 2: Distribution of Giving out Receipts/Invoices

Domestic and household service Maintenance and repair of the dwelling Recreational and sporting services Paramedical services

Personal grooming establishment Maintenance and repairs Tobacco Local transpor Medical services Catering services Accommodation services Spare parts and accessorie Newspapers, magazines, books Package holidays Purchase of vehicles Property insurance Veterinary services

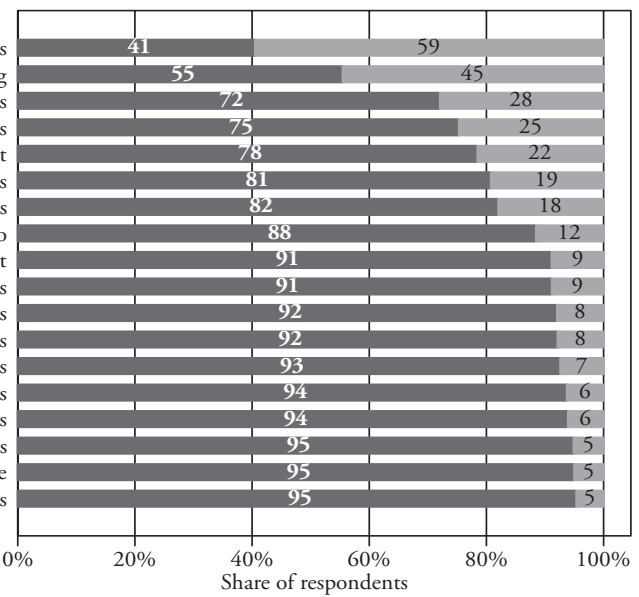

Source: Authors' calculation. 
At the top of the figure we can see that the domestic and household services and maintenance and repair of the dwelling have the greatest share or transactions without a receipt (59 percent and 45 percent, respectively). Expenditure groups, where a receipt/invoice is given in less than one in five times also include recreational and sporting activities (28 percent), paramedical services (25 percent), and rent (22 percent). Although this might hint at the sectors where most of the money 'goes under the table', we need to account for the actual expenditure for these product groups to see the monetary scope of these hidden transactions.

After calculating the payment method shares in each expenditure group, we multiply these shares with the average expenditure per household in 2014 in EUR, as presented in Table 3. The second column in the mentioned table presents the average expenditures in EUR per household in 2014, taken from the HBS.

It is clear from this data that in 2014 an average Croatian household spent most of its income on food (EUR 2,912.31), utilities (EUR 1,566.18), and fuel (EUR 739.45); while the lowest amount of income was spent on postal services (EUR 5.90), sports and recreation (EUR 8.26), and property insurance (EUR 9.31). The following six columns present the share of certain payment methods used when purchasing these goods/services (calculated from our survey) and the actual monetary value of those payments. Last four columns concentrate only on cash as a payment method and present a share of transactions with and without a receipt/invoice and the expenditure amount associated with each of these cases.

By concentrating on card payment firstly, we can see that even though the expenditures for equipment and appliances for the house and garden have the greatest share or card payments ( 73.47 percent), they are nonetheless dominated by the expenditures for food when it comes to actual monetary expenditure (EUR 1,388.77 for food and EUR 417.71 for equipment and appliances for the house and garden). Beside these two categories, the highest expenditure paid using cards goes to clothing and footwear (EUR 503.24) and fuel (EUR 456.78) purchases. 


\begin{tabular}{|c|c|c|c|c|c|c|c|c|c|c|c|c|c|c|c|c|c|c|c|c|c|c|c|c|}
\hline 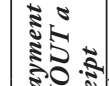 & 各 & $\frac{6}{i}$ & $\stackrel{\infty}{\infty}$ & 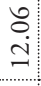 & $\stackrel{\vec{n}}{\text { in }}$ & $\stackrel{?}{\stackrel{\imath}{二}}$ & 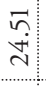 & $\begin{array}{l}0 \\
\stackrel{1}{4} \\
2\end{array}$ & 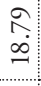 & $\stackrel{\infty}{\stackrel{f}{c}}$ & $\stackrel{\leftrightarrow}{n}$ & $\frac{\grave{2}}{\grave{c}}$ & $\stackrel{0}{\circ}$ & $\underset{+}{+}$ & \begin{tabular}{l} 
ț \\
\multirow{+}{*}{}
\end{tabular} & $\hat{\sigma}$ & $\hat{\text { in }}$ & $\frac{10}{0}$ & $\stackrel{m}{+}$ & $\stackrel{\infty}{\stackrel{\infty}{\sim}}$ & $\begin{array}{c}\infty \\
\text { in }\end{array}$ & $\begin{array}{l}\stackrel{0}{0} \\
\dot{r}\end{array}$ & $\vec{m}$ & $\hat{\tilde{o}}$ \\
\hline 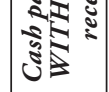 & $0^{\circ}$ & $\begin{array}{l}\text { tit } \\
\text { रे }\end{array}$ & $\stackrel{\tilde{N}}{\stackrel{F}{+}}$ & ते & $\begin{array}{c}\infty \\
0 \\
\sim \\
\sim\end{array}$ & $\stackrel{\sim}{\grave{i}}$ & $\stackrel{\sim}{\tilde{2}}$ & $\frac{2}{2}$ & $\bar{n}$ & $\begin{array}{c}n \\
\infty \\
\infty\end{array}$ & $\begin{array}{l}\infty \\
\infty \\
\infty\end{array}$ & $\stackrel{\kappa}{\kappa}$ & $\stackrel{+}{\infty}$ & $\stackrel{\infty}{\stackrel{\infty}{i}}$ & તู & bे & $\begin{array}{c}0 \\
\text { in }\end{array}$ & $\begin{array}{l}8 \\
\dot{0} \\
\text { in }\end{array}$ & $\left(\begin{array}{l}++ \\
+ \\
+\end{array}\right.$ & $\begin{array}{l}B \\
\text { i }\end{array}$ & $\begin{array}{l}+ \\
0 \\
\stackrel{N}{*}\end{array}$ & 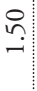 & $\stackrel{\stackrel{f}{-}}{:}$ & $\stackrel{\stackrel{I}{S}}{\sim}$ \\
\hline 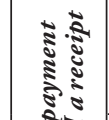 & 各 & $\hat{\imath}$ & ते & $\frac{1}{m}$ & $\stackrel{+}{\circ}$ & $\frac{0}{\mathrm{i}}$ & $\begin{array}{c}0 \\
\text { ஸे } \\
0\end{array}$ & $\frac{7}{m}$ & \begin{tabular}{l}
+ \\
$\dot{f}$ \\
\multirow{4}{*}{}
\end{tabular} & $\frac{n}{2}$ & $\hat{\grave{n}}$ & ì & $\tilde{\infty}$ & 感 & $\begin{array}{l}\hat{\varkappa} \\
\stackrel{\sigma}{0}\end{array}$ & $\begin{array}{l}n \\
\stackrel{n}{\sim}\end{array}$ & $\stackrel{\infty}{\infty}$ & $\stackrel{\infty}{\infty}$ & $\frac{n}{\infty}$ & $\begin{array}{c}\stackrel{c}{O} \\
\infty \\
\infty \\
+\end{array}$ & $\frac{\infty}{2}$ & 命: & $\begin{array}{c}2 \\
\infty \\
\infty \\
0 \\
\end{array}$ & 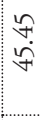 \\
\hline है. & $0^{\circ}$ & ì & 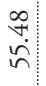 & $\begin{array}{l}a \\
\text { ì } \\
\text { in }\end{array}$ & $\begin{array}{l}n \\
n \\
n\end{array}$ & 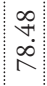 & $\begin{array}{c}\infty \\
\stackrel{1}{0} \\
\infty\end{array}$ & $\begin{array}{l}n \\
\hat{d} \\
\infty\end{array}$ & $\begin{array}{l}\stackrel{f}{+} \\
\infty \\
\infty\end{array}$ & $\frac{n}{a}$ & $\frac{\infty}{a}$ & $\begin{array}{c}\hat{b} \\
\hat{i}\end{array}$ & $\frac{\circ}{\grave{\alpha}}$ & $\begin{array}{c}\hat{\sigma} \\
\alpha \\
\alpha\end{array}$ & $\stackrel{n}{\kappa}$ & $\begin{array}{l}\dot{a} \\
\dot{\sigma}\end{array}$ & 吕 & $\begin{array}{l}\stackrel{8}{0} \\
\stackrel{1}{\alpha}\end{array}$ & ñ & 吕 & & $\begin{array}{l}\stackrel{\circ}{n}, \\
\infty \\
\infty\end{array}$ & $\stackrel{n}{n}$ & $\begin{array}{l}\stackrel{2}{\infty} \\
\infty \\
\infty\end{array}$ \\
\hline కั้ & 各 & $\begin{array}{l}0 \\
0 \\
2\end{array}$ & $\frac{\tilde{n}}{\hat{n}}$ & $\begin{array}{l}\hat{N} \\
\infty \\
+\end{array}$ & $\hat{n}$ & $\frac{N}{i n}$ & $\begin{array}{l}\hat{n} \\
\hat{\imath}\end{array}$ & $\frac{\hat{n}}{\dot{\nabla}}$ & $\begin{array}{l}0 \\
\sim \\
\tilde{\sigma} \\
-1\end{array}$ & $\begin{array}{c}\alpha \\
\grave{n} \\
\infty\end{array}$ & & $\begin{array}{l}\stackrel{i}{d} \\
\stackrel{i}{N}\end{array}$ & & o & $\widehat{\vec{t}}$ & 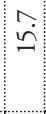 & $\frac{n}{2}$ & $\stackrel{\tilde{r}}{\dot{m}}$ & ñ & 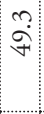 & 党: & 芦 & 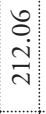 & 웅 \\
\hline हैँ & $0^{\circ}$ & வி & $\begin{array}{l}\hat{\alpha} \\
\alpha \\
\alpha\end{array}$ & $\stackrel{\leftrightarrow}{\mathrm{i}}$ & $\begin{array}{l}n \\
\hat{a}\end{array}$ & 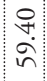 & 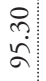 & 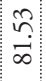 & ڤ̀ & $\frac{\sqrt{x}}{\not{a}}$ & $\begin{array}{c}5 \\
\infty \\
\infty\end{array}$ & $\begin{array}{l}\infty \\
\grave{\alpha}\end{array}$ & ते & 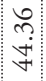 & 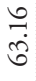 & $\begin{array}{c}n \\
\infty \\
\infty \\
\sim\end{array}$ & $\hat{\grave{n}}$ & $\begin{array}{l}\approx \\
\approx i \\
\approx n\end{array}$ & $\begin{array}{c}n \\
\infty \\
\infty\end{array}$ & $\begin{array}{l}\hat{1} \\
\hat{f}\end{array}$ & ஸ̂: & $\begin{array}{l}\overrightarrow{1} \\
\hat{n}\end{array}$ & $\frac{f}{2}$ & ه़ \\
\hline ป & $\begin{array}{l}\text { s. } \\
\text { |r }\end{array}$ & $\begin{array}{l}8 \\
0\end{array}$ & $\begin{array}{l}8 \\
0\end{array}$ & $\begin{array}{l}0 \\
\text { nn } \\
\text { n. }\end{array}$ & ஸे & $\frac{\hat{\partial}}{\hat{\lambda}}$ & $\begin{array}{l}8 \\
0\end{array}$ & $\stackrel{n}{0}$ & $\underline{-}$ & 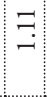 & $\begin{array}{l}+ \\
\infty \\
0\end{array}$ & $\stackrel{+}{\circ}$ & $\sim \sim$ & $\stackrel{9}{\rightarrow}$ & $\begin{array}{l}\text { ț } \\
\underset{+}{*}\end{array}$ & $\stackrel{\infty}{1}$ & 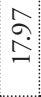 & $\stackrel{m}{m}$ & $\stackrel{7}{0}$ & $\begin{array}{l}\hat{\alpha} \\
\ddot{d}\end{array}$ & $\stackrel{0}{0}$ & $\begin{array}{l}8 \\
0 \\
0\end{array}$ & $\stackrel{\Re}{\mathfrak{r}}$ & 8 \\
\hline$\Xi$ & $0^{\circ}$ & : & $\begin{array}{l}0 \\
0 \\
0\end{array}$ & $\dot{a}$ & $\frac{0}{\dot{n}}$ & $\begin{array}{c}\infty \\
\dot{o} \\
\ddot{m}\end{array}$ & $\begin{array}{l}0 \\
0 \\
0\end{array}$ & $\frac{\tilde{c}}{i}$ & $\hat{n}$ & $\stackrel{\hat{\imath}}{\stackrel{2}{\sim}}$ & 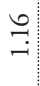 & $\stackrel{0}{\circ}$ & $\begin{array}{l}\mathfrak{\sigma} \\
\dot{n}\end{array}$ & $i n$ & $\tilde{\kappa}$ & $\frac{+}{0}$ & $\begin{array}{c}0 \\
a\end{array}$ & $\hat{\hat{\alpha}}$ & : & $\begin{array}{l}\hat{b} \\
\dot{\lambda}\end{array}$ & $\underset{\infty}{\infty}$ & $\begin{array}{l}0 \\
: \\
0\end{array}$ & : & 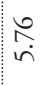 \\
\hline $\begin{array}{l}5 \\
5 \\
5 \\
3 \\
3\end{array}$ & $\underset{\text { 号 }}{\text { 品 }}$ & $\begin{array}{l}8 \\
0\end{array}$ & \begin{tabular}{l}
$\stackrel{\circ}{0}$ \\
\hdashline
\end{tabular} & $\stackrel{\circ}{\circ}$ & $\stackrel{N}{\infty}$ & $\stackrel{\infty}{0}$ & तु & $\begin{array}{l}\infty \\
\infty \\
\infty\end{array}$ & $\begin{array}{l}\bar{n} \\
\dot{n}\end{array}$ & 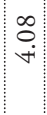 & $\begin{array}{l}0 \\
0 \\
\dot{x}\end{array}$ & $\begin{array}{l}0 \\
\ddot{n}\end{array}$ & $\begin{array}{l}\vec{n} \\
\grave{v}\end{array}$ & $\frac{\hat{n}}{\hat{n}}$ & $\begin{array}{l}\tilde{b} \\
\infty \\
\infty \\
\infty\end{array}$ & î. & : & $\hat{i}$ & ते & के & $\frac{N}{\sim}$ & $\left.\begin{array}{l}\infty \\
\infty \\
\dot{n} \\
n\end{array}\right]$ & 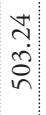 & $\stackrel{t}{\stackrel{t}{2}}$ \\
\hline & $0^{\circ}$ & 8 & $\stackrel{n}{-}$ & $\begin{array}{l}+ \\
\infty \\
\infty \\
\infty\end{array}$ & $\begin{array}{l}\hat{x} \\
n\end{array}$ & $\stackrel{N}{2}$ & $\stackrel{P}{\stackrel{P}{+f}}$ & $\stackrel{f}{\stackrel{4}{~}}$ & $\begin{array}{l}\hat{n} \\
\text { ते }\end{array}$ & $\stackrel{\infty}{\stackrel{\infty}{\sim}}$ & 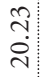 & $\begin{array}{l}\infty \\
\infty \\
\infty\end{array}$ & $\begin{array}{l}+ \\
\text { ते }\end{array}$ & $\begin{array}{l}\hat{b} \\
\hat{n}\end{array}$ & $\begin{array}{l}\text { के } \\
\text { ì }\end{array}$ & $\begin{array}{l}4 \\
2 \\
\text { in }\end{array}$ & $\begin{array}{c}n \\
\hat{n} \\
\hat{n}\end{array}$ & $\frac{\vec{\alpha}}{\dot{m}}$ & $\underset{\sigma}{\infty}$ & $\begin{array}{l}b \\
\text { in }\end{array}$ & $\stackrel{n}{\dot{d}}$ & $\begin{array}{l}\infty \\
\infty \\
\dot{f}\end{array}$ & $\begin{array}{c}\infty \\
\dot{\sigma}\end{array} \mid$ & $\stackrel{\infty}{\stackrel{\sim}{\sim}}$ \\
\hline 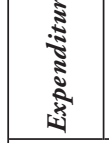 & 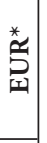 & $\begin{array}{l}0 \\
0 \\
2\end{array}$ & $\stackrel{n}{\tilde{N}}$ & $\begin{array}{l}\text { ⿵人} \\
\hat{n}\end{array}$ & $\stackrel{n}{=}$ & ff & $\begin{array}{l}\infty \\
m \\
\end{array}$ & $\begin{array}{l}\infty \\
\grave{2}\end{array}$ & $\begin{array}{l}+ \\
\Delta \\
\vec{N}\end{array}$ & $\frac{7}{\infty}$ & 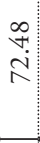 & 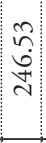 & $\begin{array}{c}\hat{n} \\
\text { के }\end{array}$ & $\hat{\imath}$ & 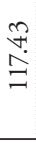 & $\begin{array}{l}f \\
\dot{n}\end{array}$ & ஸู & $\vec{\sigma}$ & 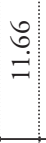 & $\stackrel{+}{=}$ & $\begin{array}{l}0 \\
\stackrel{0}{0} \\
\infty\end{array}$ & 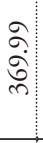 & $\begin{array}{l}0 \\
0 \\
i \\
i\end{array}$ & $\frac{\mathfrak{L}}{\mathscr{b}}$ \\
\hline 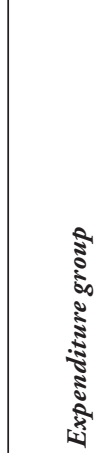 & & 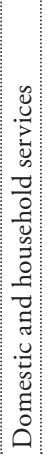 & 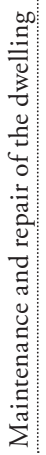 & 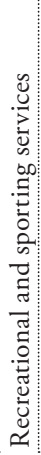 & 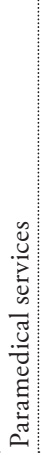 & $\stackrel{\overrightarrow{4}}{2}$ & 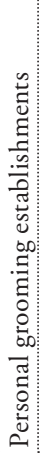 & 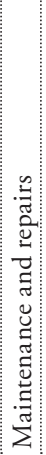 & $\begin{array}{l}0 \\
y \\
\tilde{n} \\
0 \\
0\end{array}$ & 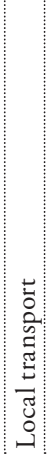 & 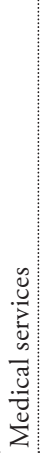 & 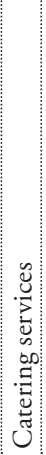 & 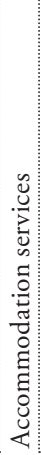 & 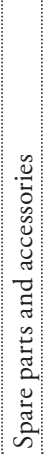 & 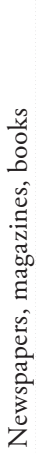 & 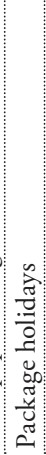 & 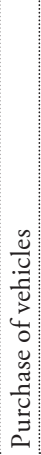 & 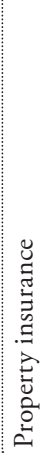 & 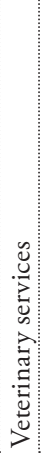 & : & 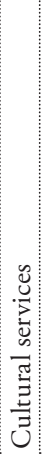 & 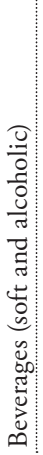 & 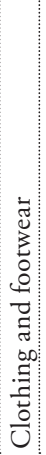 & $\frac{5}{0}$ \\
\hline
\end{tabular}




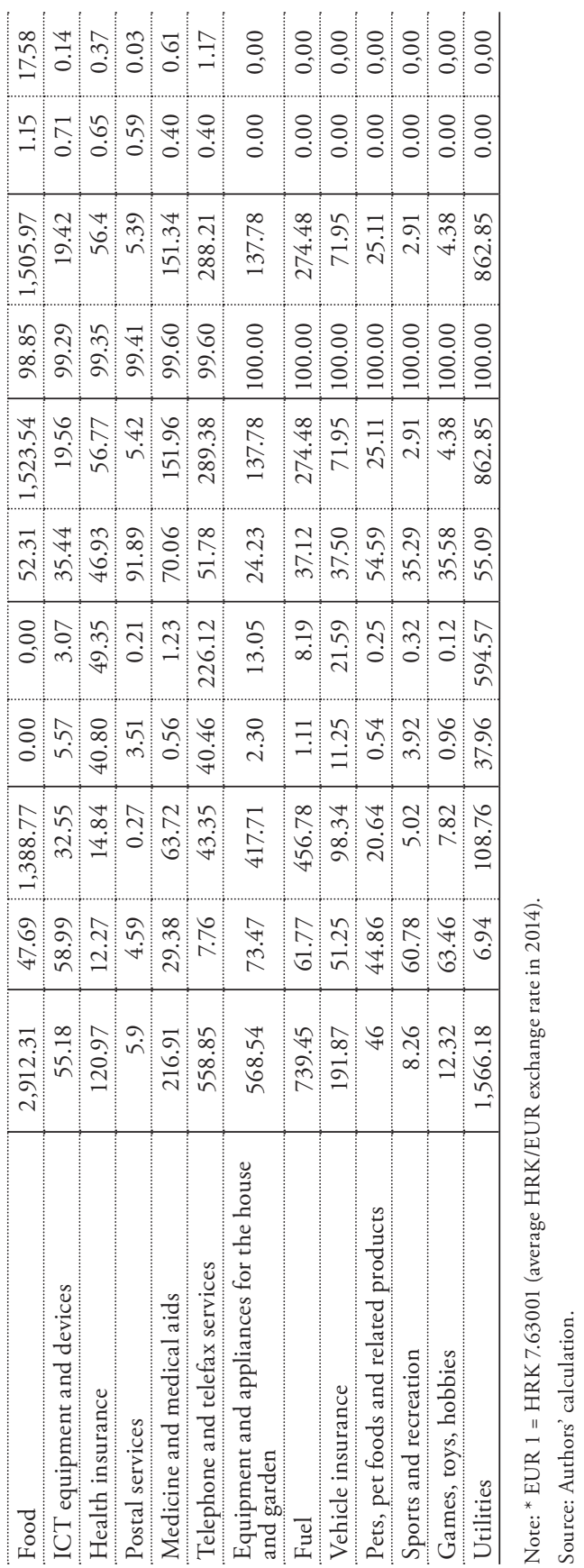


As far as electronic payment is concerned, it is mostly used to buy health insurance (in 40.8 percent of cases), which translates to only EUR 49.35 per household on average. Utilities are the winner here, paid electronically in 37.96 percent of cases, amounting up to EUR 594.57. Other big electronically-paid expenditure items are the telephone and telefax services (EUR 226.12) and rent (EUR 29.92).

Next, in terms of cash payments, the situation is quite similar. 100 percent of domestic and household services are paid in cash, but this only amounts to EUR 19.66 on average per household. On the other hand, roughly half of the food purchases are paid in cash (52.31 percent), but in terms of monetary value, this amounts to EUR 1,523.54. Half of the utility bills are also paid in cash (55.09 percent), which amounts to EUR 862.85 per household on average.

Lastly, we analyze the frequency of issuing receipts/invoices connected with cash payments. Both of the expenditure items mentioned above, i.e. food and utilities, which bring substantial cash inflow to sellers, are scored very highly in terms of being able to get a receipt for these kinds of purchases (98.85 percent and 100 percent, respectively). We can therefore conclude that in the two most cashheavy expenditure groups, issuing a receipt is not a problem, which indicates that we should not expect to look for clues of a shadow economy here. On the other hand, domestic and household services are exclusively paid in cash (100 percent of times), and out of those, in more than every second case (59.46 percent) the seller failed to issue a receipt. In monetary terms, however, this only amounts to EUR 11.69 per household on average. On the other hand, maintenance and repair of the dwelling activities are paid in cash 98.95 percent of the time, and the receipt was not issued in 44.52 percent of cases, which amounts to EUR 31.87 per household on average. The distribution of other expenditure groups based on the monetary value of the receipts not issued is presented in Figure 3. Expenditure groups that fall between EUR 10 and EUR 30 of unissued receipts per household on average include: personal grooming establishments, tobacco, catering services, food, recreational and sporting activities, domestic and household services, and rent. 
On aggregate, total average cash payments without an issued receipt amounted up to EUR 196.71 per household in 2014. This may not seem like much, but some back-of-the envelope calculations show that this amount is not insignificant. Namely, based on the 2011 population census, there were 1,519,038 households in Croatia. This means that for 2014, the amount of hidden transactions was in the excess of EUR 298 million, which is around 0.69 percent of GDP in the same year. Obviously, this estimate represents only a small fraction of Croatia's unofficial economy.

Figure 3: Distribution of Unreported Expenditures (EUR) in Different Expenditure Groups per Household in 2014, on Average

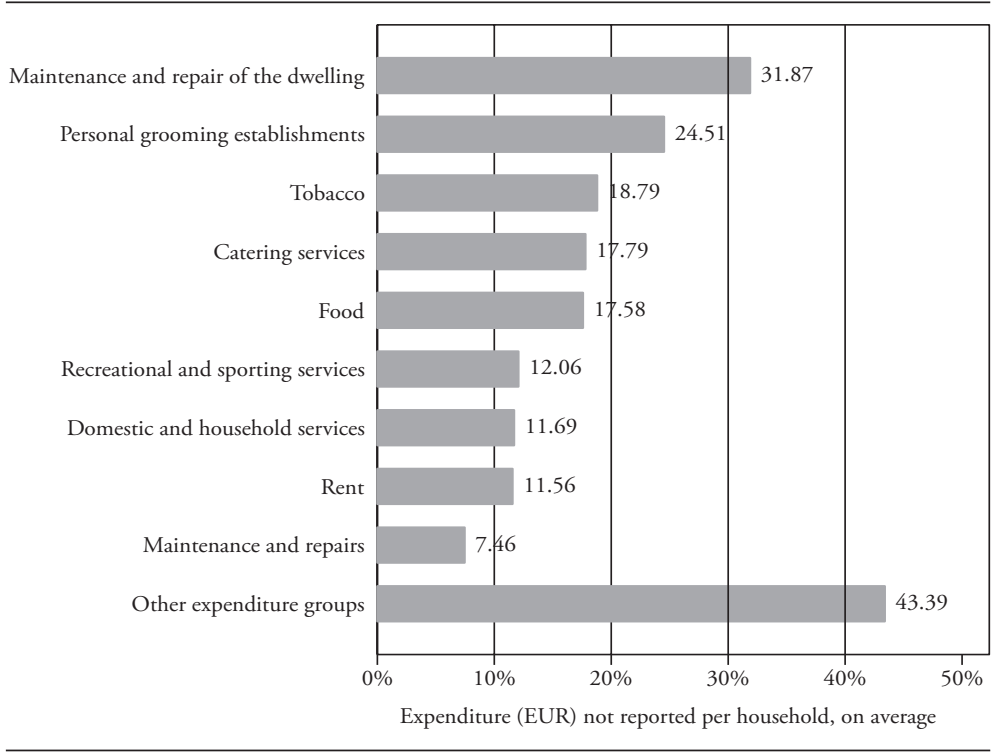

Source: Authors' calculation.

\section{Conclusion}

In this paper we estimate a part of the unofficial economy connected to household consumption. The approach adopted for the purpose of this research is limited to the consumption of goods and services by households and as such cannot be used 
to estimate the outright volume of the informal sector in the economy. However, it offers useful insights into the structure of lost government revenues in various different categories of goods and services. This is fundamental information for policy makers, which will enable the creation of policies, measures and controls aimed at certain enterprises that demonstrated an increased propensity toward informal economic activities, which, in turn, could facilitate a more efficient battle against the unofficial economy.

We found that domestic and household services, maintenance and repair of dwellings, personal grooming establishments, local transport, postal, and catering services are paid exclusively or predominantly in cash. These services, along with recreational and sporting activities, also represent categories with the highest share of unissued invoices. This simple glance at household consumption data might serve as a guideline when implementing policies aimed at seizing the unofficial economy. Based on the latest household consumption survey data of 2014, estimated unofficial economy from household consumption was around EUR 298 million, or 0.69 percent of GDP.

It would be unwise to conclude that these estimates encompass the full extent of the unofficial economy in Croatia. Since the method applied measures only a part of the overall unofficial economy, it probably estimates a lower bound of the unofficial economy. Therefore, our estimates rather serve as an indicator of a part of the unofficial sector hidden in day-to-day transactions of households. This also proves to be one of the main contributions of this paper: to estimate the unofficial economy based on survey data, which does not suffer from non-reporting bias and is in line with suggestions made by Schneider and Buehn (2016) on the development of new methodologies and estimation strategies aimed at tackling the ever-changing and complex issue of the unofficial economy.

Acknowledgement: The authors highly appreciate the advice and assistance of our colleague Edo Rajh provided throughout the whole research project. We also thank the reviewers for suggestions that improved our work. Remaining errors are, however, of our own. 


\section{Appendix}

Table A.1: Distribution of Respondents by Gender, Age, and County

\begin{tabular}{|c|c|c|c|c|c|c|c|c|c|c|c|}
\hline \multirow[b]{2}{*}{ County / Age, Gender } & \multicolumn{5}{|c|}{ Female } & \multicolumn{5}{|c|}{ Male } & \multirow[b]{2}{*}{ TOTAL } \\
\hline & $\begin{array}{c}18- \\
24\end{array}$ & $\begin{array}{c}25- \\
34\end{array}$ & $\begin{array}{c}35- \\
44\end{array}$ & $\begin{array}{c}45- \\
54 \\
\end{array}$ & $\begin{array}{c}55- \\
64 \\
\end{array}$ & $\begin{array}{c}18- \\
24\end{array}$ & $\begin{array}{c}25- \\
34 \\
\end{array}$ & $\begin{array}{c}35- \\
44 \\
\end{array}$ & $\begin{array}{c}45- \\
54 \\
\end{array}$ & $\begin{array}{c}55- \\
64 \\
\end{array}$ & \\
\hline Bjelovar-Bilogora & 1 & 1 & 1 & 2 & 1 & 1 & 2 & 2 & 2 & 1 & 14 \\
\hline Brod-Posavina & 1 & 2 & 2 & 2 & 1 & 2 & 2 & 2 & 2 & 1 & 17 \\
\hline City of Zagreb & 6 & 12 & 12 & 12 & 12 & 6 & 11 & 11 & 10 & 10 & 102 \\
\hline Dubrovnik-Neretva & 1 & 2 & 1 & 1 & 1 & 1 & 2 & 2 & 2 & 2 & 15 \\
\hline Istria & 2 & 3 & 3 & 3 & 2 & 2 & 2 & 3 & 3 & 3 & 26 \\
\hline Karlovac & 1 & 2 & 1 & 2 & 2 & 1 & 2 & 1 & 1 & 2 & 15 \\
\hline Koprivnica-Križevci & 1 & 1 & 2 & 1 & 2 & 1 & 1 & 2 & 2 & 2 & 15 \\
\hline Krapina-Zagorje & 1 & 2 & 1 & 2 & 0 & 0 & 2 & 1 & 2 & 2 & 13 \\
\hline Lika-Senj & 0 & 1 & 0 & 1 & 1 & 0 & 1 & 1 & 1 & 1 & 7 \\
\hline Međimurje & 1 & 1 & 2 & 2 & 1 & 1 & 2 & 2 & 2 & 1 & 15 \\
\hline Osijek-Baranja & 3 & 4 & 3 & 5 & 2 & 1 & 4 & 4 & 5 & 4 & 35 \\
\hline Požega-Slavonia & 1 & 1 & 1 & 1 & 1 & 1 & 1 & 1 & 1 & 1 & 10 \\
\hline Primorje-Gorski Kotar & 2 & 4 & 3 & 5 & 5 & 2 & 2 & 4 & 4 & 3 & 34 \\
\hline Sisak-Moslavina & 1 & 1 & 1 & 1 & 1 & 1 & 1 & 1 & 1 & 2 & 11 \\
\hline Split-Dalmatia & 0 & 2 & 2 & 3 & 3 & 1 & 1 & 2 & 2 & 2 & 18 \\
\hline Šibenik-Knin & 1 & 6 & 3 & 4 & 5 & 4 & 6 & 6 & 7 & 6 & 48 \\
\hline Varaždin & 1 & 0 & 2 & 3 & 2 & 2 & 3 & 2 & 3 & 1 & 19 \\
\hline Virovitica-Podravina & 1 & 1 & 1 & 1 & 1 & 1 & 1 & 1 & 0 & 1 & 9 \\
\hline Vukovar-Srijem & 2 & 2 & 2 & 3 & 2 & 2 & 2 & 2 & 3 & 2 & 22 \\
\hline Zadar & 1 & 2 & 2 & 2 & 2 & 1 & 2 & 1 & 2 & 1 & 16 \\
\hline Zagreb & 3 & 4 & 4 & 4 & 2 & 3 & 5 & 5 & 5 & 4 & 39 \\
\hline TOTAL & 31 & 54 & 49 & 60 & 49 & 34 & 55 & 56 & 60 & 52 & 500 \\
\hline
\end{tabular}

Source: Authors' calculation. 
Table A.2: Defining Croatian Regions

\begin{tabular}{|c|c|}
\hline Region & County \\
\hline \multirow{5}{*}{ Central Croatia } & City of Zagreb \\
\hline & Zagreb \\
\hline & Karlovac \\
\hline & Sisak-Moslavina \\
\hline & Bjelovar-Bilogora \\
\hline \multirow{4}{*}{ Northwest Croatia } & Krapina-Zagorje \\
\hline & Koprivnica-Križevci \\
\hline & Varaždin \\
\hline & Međimurje \\
\hline \multirow{5}{*}{ East Croatia } & Virovitica-Podravina \\
\hline & Osijek-Baranja \\
\hline & Vukovar-Sirmium \\
\hline & Slavonski Brod-Posavina \\
\hline & Požega-Slavonia \\
\hline \multirow{3}{*}{ North Adriatic and Lika } & Istria \\
\hline & Primorje-Gorski Kotar \\
\hline & Lika-Senj \\
\hline \multirow{4}{*}{ Central and South Adriatic } & Zadar \\
\hline & Šibenik-Knin \\
\hline & Split-Dalmatia \\
\hline & Dubrovnik-Neretva \\
\hline
\end{tabular}

Source: Authors' construction.

Table A.3: Matching Table for Expenditure Groups

\begin{tabular}{|c|c|c|}
\hline Our Expenditure groups & CBS Expenditure groups & CBS codes \\
\hline Food & Food & 01.1 \\
\hline Beverages (soft and alcoholic) & Non-alcoholic beverages + Alcoholic beverages & $01.2+02.1$ \\
\hline Cigarettes and tobacco & Tobacco & 02.2 \\
\hline Clothes and shoes & Clothing and footwear & 03 \\
\hline Rent & Actual rentals for housing & 04.1 \\
\hline $\begin{array}{l}\text { Small dwelling maintenance, } \\
\text { small building work }\end{array}$ & Maintenance and repair of the dwelling & 04.3 \\
\hline $\begin{array}{l}\text { Utilities (water, electricity, } \\
\text { heating, gas, waste removal) }\end{array}$ & $\begin{array}{l}\text { Water supply and miscellaneous services relating } \\
\text { to the dwelling + Electricity, gas and other fuels }\end{array}$ & $04.4+04.5$ \\
\hline $\begin{array}{l}\text { Furniture, appliances, } \\
\text { equipment for the house and } \\
\text { garden }\end{array}$ & $\begin{array}{l}\text { Furniture and furnishing, carpets and other } \\
\text { floor coverings + Household textiles + Major } \\
\text { household appliances + Small electric household } \\
\text { appliances + Glassware and tableware utensils } \\
+ \text { Gardens, plants and flowers + Electrical } \\
\text { appliances for personal care + Other articles and } \\
\text { products for personal care }\end{array}$ & $\begin{array}{l}05.1+05.2+ \\
05.3 .1+05.3 .2 \\
+05.4+05.5+ \\
09.3 .3+12.1 .2 \\
+12.1 .3\end{array}$ \\
\hline
\end{tabular}




\begin{tabular}{|c|c|c|}
\hline $\begin{array}{l}\text { Housekeeping services, } \\
\text { gardeners, nannies }\end{array}$ & Domestic services and household services & 05.6 .2 \\
\hline Medicine and medical aids & Medical products, appliances and equipment & 06.1 \\
\hline $\begin{array}{l}\text { Medical services in the private } \\
\text { and public sector (doctor, } \\
\text { dentist, hospital etc.) }\end{array}$ & $\begin{array}{l}\text { Medical services + Dental services + Hospital } \\
\text { services }\end{array}$ & $\begin{array}{l}06.2 .1+06.2 .2 \\
+06.3\end{array}$ \\
\hline Alternative medicine, massage & Paramedical services & 06.2 .3 \\
\hline $\begin{array}{l}\text { Purchase of vehicles (car, } \\
\text { motorcycle, bike) }\end{array}$ & Purchase of vehicles & 07.1 \\
\hline $\begin{array}{l}\text { Spare parts and equipment for } \\
\text { cars, bikes and motorcycles }\end{array}$ & Spare parts and accessories & 07.2 .1 \\
\hline Fuel & Fuel and lubricants & 07.2 .2 \\
\hline $\begin{array}{l}\text { Mechanic, tire repairman, } \\
\text { electrician, auto repair }\end{array}$ & Maintenance and repairs & 07.2 .3 \\
\hline $\begin{array}{l}\text { Train, plane, ship and long- } \\
\text { distance bus services }\end{array}$ & $\begin{array}{l}\text { Passenger transport by railway, air, sea and } \\
\text { inland waterways }\end{array}$ & $\begin{array}{l}07.3 .1+07.3 .3 \\
+07.3 .4\end{array}$ \\
\hline Local transport (bus, tram) & Passenger transport by road & 07.3 .2 \\
\hline Postal services & Postal services & 08.1 \\
\hline $\begin{array}{l}\text { Phone, fax, Internet, phone } \\
\text { (bills) }\end{array}$ & Telephone and telefax services & 08.3 \\
\hline $\begin{array}{l}\text { ICT equipment and devices } \\
\text { (computer and peripherals, } \\
\text { mobile phone, tablet) }\end{array}$ & $\begin{array}{l}\text { Information processing equipment }+ \text { Recording } \\
\text { media + Telephone and telefax equipment }\end{array}$ & $\begin{array}{l}09.1 .3+09.1 .4 \\
+08.2\end{array}$ \\
\hline Toys & Games, toys, hobbies & 09.3 .1 \\
\hline Sports and recreation & $\begin{array}{l}\text { Equipment for sport, camping and open-air } \\
\text { recreation }\end{array}$ & 09.3 .2 \\
\hline $\begin{array}{l}\text { Pets (purchasing, nutrition, } \\
\text { equipment) }\end{array}$ & Pets, pet foods and related products & 09.3 .4 \\
\hline Veterinary services & Veterinary and other services & 09.3 .5 \\
\hline $\begin{array}{l}\text { Recreation and sports } \\
\text { (membership fees, registration } \\
\text { fees, rental) }\end{array}$ & Recreational and sporting services & 09.4 .1 \\
\hline $\begin{array}{l}\text { Cultural events (cinema, } \\
\text { theater, concerts, exhibitions) }\end{array}$ & Cultural services & 09.4 .2 \\
\hline Newspapers, magazines, books & $\begin{array}{l}\text { Books + Newspapers and magazines + } \\
\text { Miscellaneous printed matter }\end{array}$ & $\begin{array}{l}09.5 .1+09.5 .2 \\
+09.5 .3\end{array}$ \\
\hline Travel trips (packages) & Package holidays & 09.6 \\
\hline Tuition, language courses etc. & Education & 10 \\
\hline $\begin{array}{l}\text { Restaurants, coffee shops, fast } \\
\text { food and bakery, dessert kiosks }\end{array}$ & Catering services & 11.1 \\
\hline Hotel accommodation & Accommodation services & 11.2 \\
\hline $\begin{array}{l}\text { Services of hairdressers, } \\
\text { beauticians, chiropodists etc. }\end{array}$ & $\begin{array}{l}\text { Hairdressing salons and personal grooming } \\
\text { establishments }\end{array}$ & 12.1 .1 \\
\hline Property insurance & Insurance related to dwellings & 12.5 .2 \\
\hline $\begin{array}{l}\text { Health insurance (additional, } \\
\text { optional) }\end{array}$ & Insurance related to health & 12.5 .3 \\
\hline $\begin{array}{l}\text { Vehicle insurance (mandatory } \\
\text { and comprehensive) }\end{array}$ & Insurance related to transport & 12.5 .4 \\
\hline
\end{tabular}

Source: Authors' construction. 


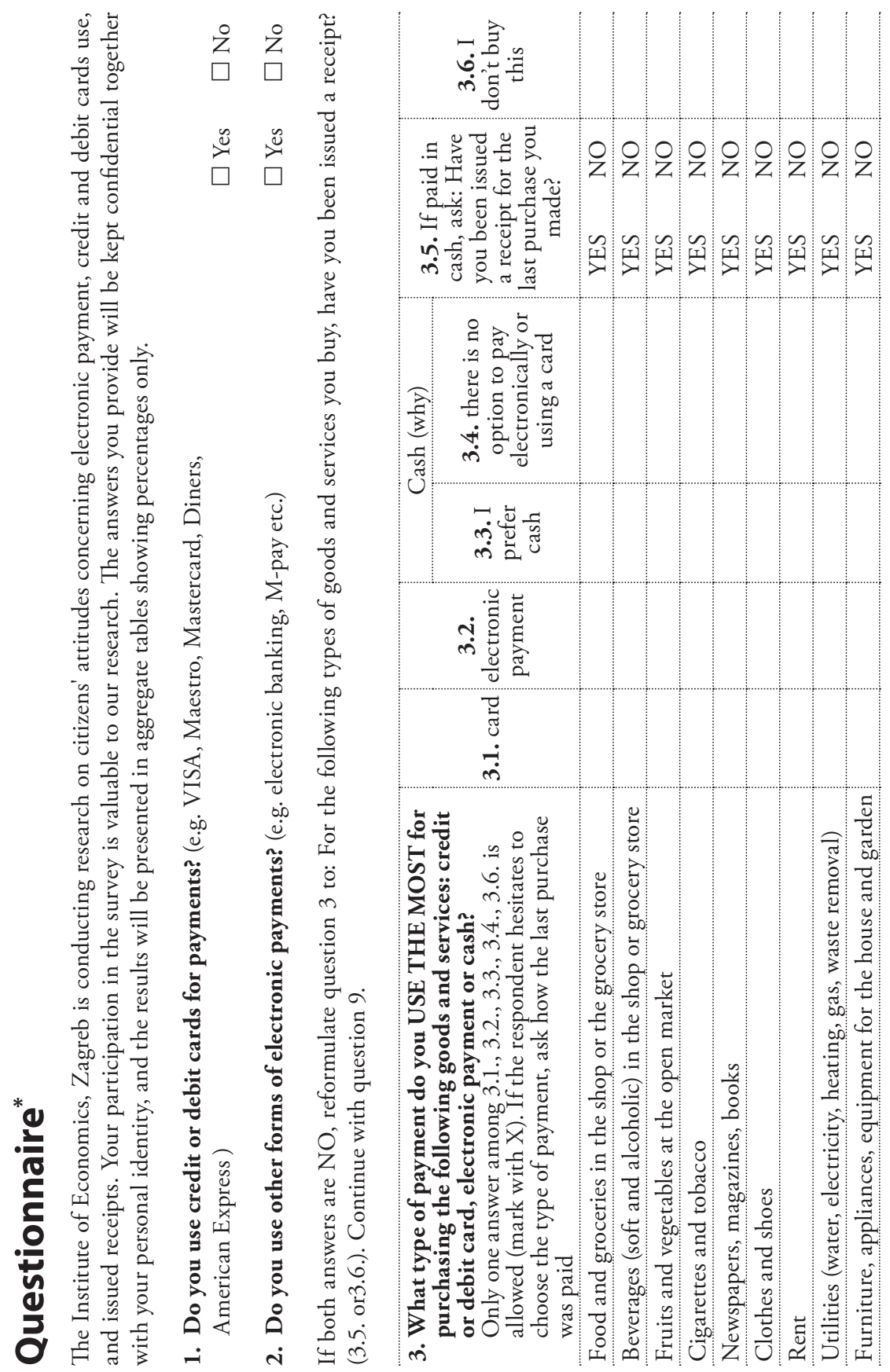




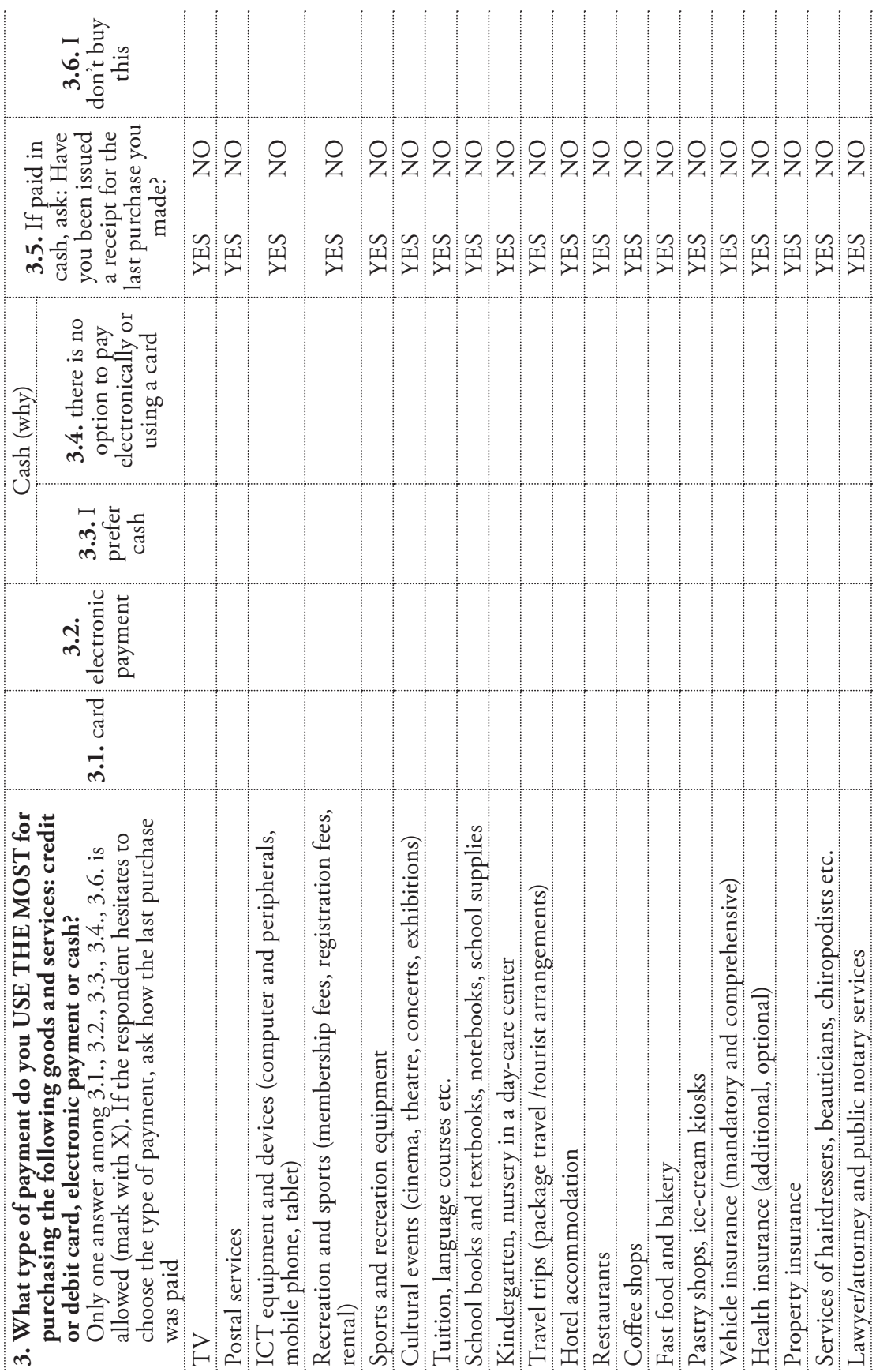



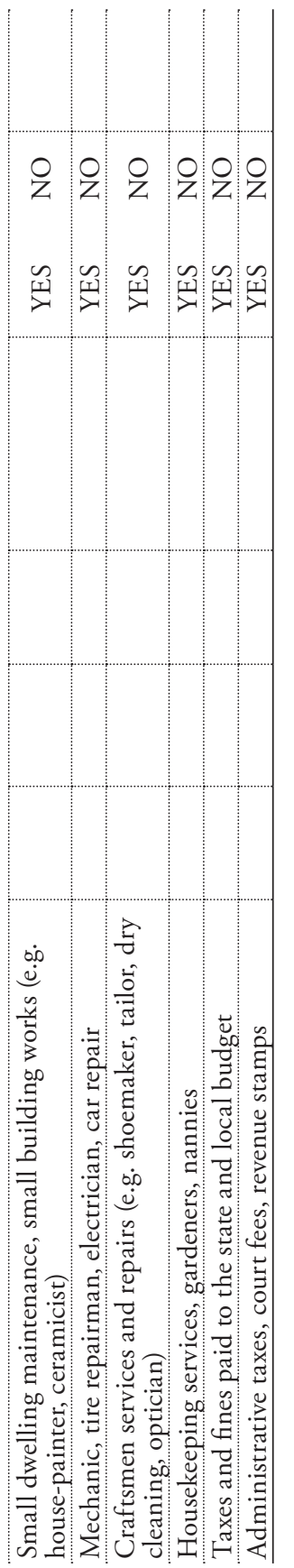

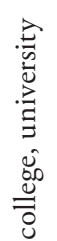

离

需

בี

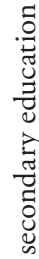

$\square$

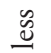

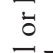

웅몰

牙霖

원

쿵유

䓀

$\square$

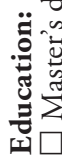

ง

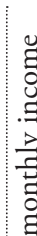

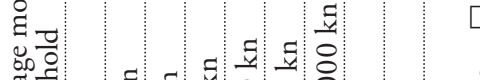

苟零

خै

4.

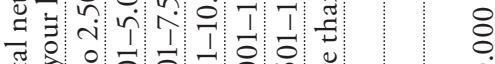

चี

I

$\stackrel{\Delta}{\square \square} \square \square \square \square \square$

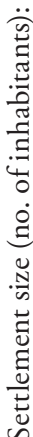

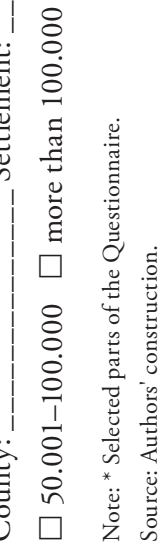




\section{Literature}

Barić, Marijana and Colin C. Williams, 2013, "Tackling the Undeclared Economy in Croatia", South-Eastern Europe Journal of Economics, 1, pp. 7-36.

Bejaković, Predrag, 2015, "A Revision of the Shadow Economy in Croatia: Causes and Effects", Economic Research, 28(1), pp. 422-440. https://doi.org/10.1 080/1331677X.2015.1059104

Božić, Ljiljana, 2017, “Telekomunikacije”, Sektorske analize, 5(4).

Commission Decision 98/5277EC of July 24, 1998 concerning the Treatment for national accounts purposes of VAT fraud (the discrepancies between theoretical VAT receipts and actual VAT receipts), Official Journal of the European Communities, L 234/39, 21/08/1998.

Croatian Bureau of Statistics (CBS), 2013, Census of Population, Households and Dwellings 2011, Zagreb: Croatian Bureau of Statistics (CBS).

Croatian Bureau of Statistics (CBS), 2016, The Household Budget Survey Revision of Data on Basic Characteristics of Household Consumption, 2014, Zagreb: Croatian Bureau of Statistics (CBS).

Croatian Parliament Decision 2822 of November 28, 2012 concerning the Cash transaction fiscalization act, http://www.fiscalization.hr/en/fiscal-law (accessed June 12, 2017).

Ernst and Young, 2016, Reducing the Shadow Economy through Electronic Payments: Croatia, Warsaw: EYGM Limited.

Franić, Josip and Colin C. Williams, 2014, "Undeclared Work in Croatia. A Baseline Assessment", GREY Working Paper, No. 2, April, Sheffield: Sheffield University Management School, University of Sheffield. http://www.greyproject.group.shef.ac.uk/wp-content/uploads/2014/09/Undeclared-Work-inCroatia-final.pdf (accessed December 15, 2017). 
Galinec, Davor, 2002, "Neslužbeno gospodarstvo u vanjskoj trgovini", Financijska teorija i praksa, 26(1), pp. 197-212.

Hanousek, Jan and Filip Palda, 2006, "Problems Measuring the Underground Economy in Transition", Economics of Transition, 14(4), pp. 707-718. https://doi. org/10.1111/j.1468-0351.2006.00268.x

Johnson, Simon, Daniel Kaufmann, John McMillan and Christopher Woodruff, 2000, "Why Do Firms Hide? Bribes and Unofficial Activity after Communism", Journal of Public Economics, 76(3), pp. 495-520.

Karajić, Nenad, 2002, "Siromaštvo i neslužbeno gospodarstvo u Hrvatskoj kvalitativni aspekti", Financijska teorija i praksa, 26(1), pp. 273-299.

Lovrinčević, Željko, Davor Mikulić and Andrea Galić Nagyszombaty, 2005, "Estimate of the Size of the Underground Economy in Croatia and the Impact on the Macroeconomic Policy" in Zlatan Reić and others, eds., Enterprise in Transition: Sixth International Conference on Enterprise in Transition (Proceedings), pp. 253-255, Split: University of Split, Faculty of Economics.

Lovrinčević, Željko, Davor Mikulić and Biserka Nikšić-Paulić, 2002, "The Official Statistics Approach to an Estimate of the Size of the Underground Economy", Financijska teorija i praksa, 26(1), pp. 83-116.

Lovrinčević, Željko, Davor Mikulić and Jelena Budak, 2006, "Corruption and Underground Economy - Two Sides of the Same Coin?" in Lovorka Galetić, ed., An Enterprise Odyssey: Integration or Disintegration (Proceedings), pp. 47-48, Zagreb: Mikrorad.

Lovrinčević, Željko, Zdravko Marić and Davor Mikulić, 2006, "Maastrichtski kriteriji i uključivanje sive ekonomije - slučaj Hrvatske", Privredna kretanja $i$ ekonomska politika, 16(106), pp. 28-65.

Luepker, Russel V., Unto E. Pallonen, David M. Murray and Phyllis L. Pirie, 1989, "Validity of Telephone Surveys in Assessing Cigarette Smoking in Young Adults", American Journal of Public Health, 79(2), pp. 202-204. https://doi. org/10.2105/AJPH.79.2.202 
Madžarević-Šujster, Sanja, 2002, "Procjena porezne evazije u Hrvatskoj", Financijska teorija i praksa, 26(1), pp. 117-144.

Madžarević, Sanja and Davor Mikulić, 1997, "Mjerenje neslužbenog gospodarstva sustavom nacionalnih računa", Financijska praksa, 21(1-2), pp. 241-258.

Madžarević-Šujster, Sanja and Davor Mikulić, 2002, "Procjena neslužbenoga gospodarstva sustavom nacionalnih računa", Financijska teorija i praksa, 26(1), pp. 31-56.

Manes, Eran, Friedrich Schneider and Anat Tchetchik, 2016, "On the Boundaries of the Shadow Economy: An Empirical Investigation", IZA Discussion Paper, No. 10067, August, Bonn: The Institute for the Study of Labor.

Marković, Branimir and Domagoj Pavić, 2013, "The Effects of Fiscalization in Suppressing Underground Economy in Catering Industry", Interdisciplinary Management Research, 9, pp. 575-584.

Maršić, Kristina and Dijana Oreški, 2016, "Estimation and Comparison of Underground Economy in Croatia and European Union Countries: Fuzzy Logic Approach", Journal of Information and Organizational Sciences, 40(1), pp. 83104.

Nastav, Bojan and Štefan Bojnec, 2007, "The Shadow Economy in Bosnia and Herzegovina, Croatia, and Slovenia: The Labor Approach", Eastern European Economics, 45(1), pp. 29-58. https://doi.org/10.2753/EEE0012-8775450102

Ott, Katarina, 2002, "Neslužbeno gospodarstvo u Republici Hrvatskoj 19902000", Financijska teorija i praksa, 26(1), pp. 1-30.

Ott, Katarina, 2004, "The Evolution of the Informal Economy and Tax Evasion in Croatia", The eJournal of Tax Research, 2(1).

Schneider, Friedrich, 2003, "Veličina i razvoj sive ekonomije i radne snage u sivoj ekonomiji u 22 tranzicijske zemlje i 21 zemlji OECD-a: Što doista znamo?", Financijska teorija i praksa, 27(1), pp. 1-29. 
Schneider, Friedrich, 2013, The Shadow Economy in Europe, Cambridge: Cambridge University Press. https://doi.org/10.1017/CBO9781139542289

Schneider, Friedrich, (ed)., 2011, Handbook on the Shadow Economy, Cheltenham: Edward Elgar Publishing Limited. https://doi.org/10.4337/9780857930880

Schneider, Friedrich, 2015, Size and Development of the Shadow Economy of 31 European and 5 other OECD Countries from 2003 to 2015: Different Developments, Linz: Johannes Kepler University.

Schneider, Friedrich and Andreas Buehn, 2016, "Estimating the Size of the Shadow Economy: Methods, Problems and Open Questions", IZA Discussion Paper, No. 9820, March, Bonn: The Institute for the Study of Labor.

Schneider, Friedrich, Andreas Buehn and Claudio Montenegro, 2010, "New Estimates for the Shadow Economies All Over the World", International Economic Journal, 24(4), pp. 443-461. https://doi.org/10.1080/10168737.2010. 525974

Schneider, Friedrich and Dominik Enste, 1998, "Increasing Shadow Economies All Over the World - Fiction or Reality", IZA Discussion Paper, No. 26, December, Bonn: The Institute for the Study of Labor.

Schneider, Friedrich and Dominik Enste, 2000, "Shadow Economies: Size, Causes and Consequences”, Journal of Economic Literature, 38(1), pp. 73-110.

Schneider, Friedrich and Dominik Enste, 2013, The Shadow Economy: An International Survey, New York, NY: Cambridge University Press. https://doi. org/10.1017/CBO9781139542289

Stockwell, Tim, Susan Donath, Mark Cooper-Stanbury, Tanya Chikritzhs, Paul Catalano and Mateo Cid, 2004, "Under-Reporting of Alcohol Consumption in Household Surveys: A Comparison of Quantity-Frequency, GraduatedFrequency and Recent Recall", Addiction, 99(8), pp. 1024-1033. https://doi. org/10.1111/j.1360-0443.2004.00815.x 
Stučka, Tihomir, 2002, "Neslužbeno gospodarstvo u turizmu", Financijska teorija i praksa, 26(1), pp. 173-195.

Szolnoki, Gergely and Dieter Hoffmann, 2013, "Online, Face-to-Face and Telephone Surveys - Comparing Different Sampling Methods in Wine Consumer Research", Wine Economics and Policy, 2(2), pp. 57-66. https://doi. org/10.1016/j.wep.2013.10.001

Šošić, Vedran and Michael Faulend, 2002, "Dolarizacija i neslužbeno gospodarstvo: slučajni partneri?", Financijska teorija i praksa, 26(1), pp. 57-81.

Švec, Marija, 2009, "Siva ekonomija u Hrvatskoj", Financijska teorija i praksa, 33(4), pp. 415-444.

Williams, Colin C., 2014, "Policy Approaches Towards Undeclared Work", GREY Working Paper, No. 4, June, Sheffield: Sheffield University Management School, University of Sheffield, http://www.grey-project.group.shef.ac.uk/ wp-content/uploads/2014/06/WP4-Policy-Approaches-Towards-UndeclaredWork1.pdf (accessed December 15, 2017). 